\title{
Corneal biomechanical evaluation in healthy thin corneas compared with matched keratoconus cases
}

\author{
Análise da biomecânica corneana em córneas finas saudáveis comparadas com \\ pacientes com ceratocone pareados por espessura corneana, sexo e idade
}

Bruno Machado Fontes ${ }^{1}$, Renato Ambrósio JR², Guillermo Coca Velarde ${ }^{3}$, Walton Nosét

\begin{abstract}
Purpose: To evaluate and compare corneal hysteresis $(\mathrm{CH})$ and corneal resistance factor (CRF) in healthy eyes with a central corneal thickness (CCT) $\leq 505 \mu$ m with $\mathrm{CH}$ and CRF in gender-, age-, and CCT-matched keratoconus cases, and to estimate the sensitivity and specificity of these parameters for discriminating between the two groups.

Methods: Prospective, comparative case series. In total 46 eyes from 30 healthy patients with CCT $\leq 505 \mu \mathrm{m}$, and 42 eyes from 30 CCT-, gender- and age-matched keratoconus cases were enrolled. Biomechanical metrics (CHand CRF) were measured using the Ocular Response Analyzer (ORA) and then compared. A receiver operating characteristic (ROC) curve was used to identify cut-off points to maximize the sensitivity and specificity for discriminating between the groups.

Results: The CCT was $485.96 \pm 17.61 \mu \mathrm{m}$ (range, $438-505)$ in healthy thin corneas and $483.64 \pm 16.19 \mu \mathrm{m}$ (range, $452-505$ ) in keratoconus; $p=0.5225$. CH was $8.63 \pm 1.23 \mathrm{mmHg}$ (range, $5.95-12.2$ ) and $8.07 \pm 1.17 \mathrm{mmHg}$ (range, $4.9-9.85$ ), respectively; $p=0.0312$. CRF was $8.43 \pm 1.29 \mathrm{mmHg}$ (range, $5.45-11.10$ ) and $7.22 \pm 1.34 \mathrm{mmHg}$ (range, 4.7 $9.45)$, respectively; $p<0.001$. ROC curve analysis showed a poor overall predictive accuracy of $\mathrm{CH}$ (cut-off, $8.95 \mathrm{mmHg}$; sensitivity, 63\%; specificity, 23.8\%; test accuracy, 44.30\%) and CRF (cut-off, $7.4 \mathrm{mmHg}$; sensitivity, 28.3\%; specificity, 40.5\%; test accuracy, $34.12 \%)$ for detecting keratoconus in the eyes studied.

Conclusion: $\mathrm{CH}$ and CRF were statistically lower in keratoconus than in healthy thin corneas. However, $\mathrm{CH}$ and CRF offered very low sensitivity and specificity for discriminating the groups.
\end{abstract}

Keywords: Cornea/physiology; Keratoconus; Corneal diseases; Biomechanics/physiology; Diagnostic techniques, ophthalmological

\section{RESUMO}

Objetivo: Avaliar e comparar a histerese corneana (CH) e o fator de resistência corneano (CRF) em olhos saudáveis com espessura corneana central (CCT) $\leq 505 \mu \mathrm{m}$ com os resultados de CH e CRF em pacientes com ceratocone pareados por sexo, idade e CCT, além de estimar a sensibilidade e especificidade destes parâmetros na diferenciação dos grupos.

Métodos: Estudo prospectivo, do tipo série de casos comparativa. No total, 46 olhos de 30 pacientes saudáveis com CCT $\leq 505 \mu \mathrm{m}$, e 42 olhos de 30 pacientes com ceratocone pareados por sexo, idade e CCT foram incluídos. Os parâmetros biomecânicos (CHe CRF) foram obtidos através do equipamento Ocular Response Analyzer (ORA) e depois comparados. Curvas ROC (Receiver operating characteristic) foram utilizadas para identificar o melhor valor de corte que apresentasse a maior sensibilidade e especificidade na discriminação entre ceratocone e córneas finas saudáveis para cada dado estudado.

Resultados: A CCT encontrada foi 485,96 $\pm 17,61 \mu \mathrm{m}$ (de 438 a 505) no grupo de córneas finas saudáveis e 483.64 $\pm 16,19 \mu \mathrm{m}$ (de 452 a 505) no grupo ceratocone, $p=0,5225$. CH 8,63 $\pm 1,23 \mathrm{mmHg}$ (de 5,95 a 12,2) e 8,07 $\pm 1,17 \mathrm{mmHg}$ (de 4,9 a 9,85), respectivamente; $p=0,0312$. CRF $8,43 \pm 1,29 \mathrm{mmHg}$ (de 5,45 a 11,10) e 7,22 $\pm 1,34 \mathrm{mmHg}$ (de 4,7 a 9,45), respectivamente; $p<0,001$. Análise das curvas $R O C$ mostrou baixa acurácia na diferenciação das córneas finas saudáveis daquelas com ceratocone tanto para $\mathrm{CH}$ (ponto de corte, $8,95 \mathrm{mmHg}$; sensibilidade, 63\%; especificidade, 23,8\%; acurácia, 44,30\%) quanto para CRF (ponto de corte, 7,4 mmHg; sensibilidade, 28,3\%; especificidade, 40,5\%; acurácia, 34,12\%).

Conclusão: Dados fornecidos pelo ORA (CH e CRF) mostraram-se estatisticamente mais baixos em pacientes com ceratocone quando comparados com córneas finas de indivíduos saudáveis. No entanto, os dois parâmetros biomecânicos estudados apresentaram sensibilidade e especificidade muito baixas na diferenciação dos grupos.

Descritores: Córnea/fisiologia; Ceratocone; Doenças da córnea; Biomecânica/fisiologia; Técnicas de diagnóstico oftalmológico

\footnotetext{
Work carried out at the Department of Ophthalmology, São Paulo Federal University - UNIFESP - São Paulo (SP), Brazil, and Renato Ambrósio Eye Institute - Rio de Janeiro (RJ), Brazil.

${ }^{1}$ Physician, Department of Ophthalmology, Federal University of São Paulo - UNIFESP - São Paulo (SP), Brazil.

2 Physician, Brazilian Society of Ophthalmology Administration - SBAO - Rio de Janeiro (RJ), Brazil. ${ }^{3}$ Biostatistician, Statistics Department, Fluminense Federal University - UFF - Rio de Janeiro (RJ), Brazil.

${ }^{4}$ Physician, Santos Metropolitan University - UNIMES - Santos (SP), Brazil; Department of Ophthalmology, Federal University of São Paulo - UNIFESP - São Paulo (SP), Brazil.

Correspondence address: Bruno M. Fontes. Av. das Acácias, 150 - BI. 2 - Apto. 1.001 - Rio de Janeiro (RJ) - CEP 22776-000 - E-mail: brunomfontes@terra.com.br

No financial support was available for this project.

Renato Ambrósio, MD is Oculus and Reichert consultant.

Recebido para publicação em 25.05.2010

Aprovação em 14.01.2011
}

\section{INTRODUCTION}

Corneal refractive surgery performed by either lamellar (LASIK) or surface (PRK, LASEK) techniques has shown safety, predictability and stability when performed in patients with healthy thin corneas ${ }^{(1-2)}$. However, proper patient selection is challenging in such cases, as preoperative thin corneas and thinner residual stromal bed after excimer laser ablation are widely described as risk factors for the development of postoperative ectasia ${ }^{(3-4)}$.

Healthy patients can present with thin corneas $(\leq 505 \mu \mathrm{m})$, and keratoconic eyes can have a "normal" ( $\leq 520 \mu \mathrm{m})$ central corneal thickness $(C C T)^{(5-8)}$. For decision making in these cases, the surgeon should rely on analysis of corneal topography and tomography data (such as corneal volume, elevation maps and pachymetric distribution $)^{(9-10)}$. The development of a test for reliable corneal stiffness assessment and response to excimer laser ablative surgery estimation is an essential step in the evolution of refractive sur$\operatorname{gery}^{(11-13)}$. 
Central corneal thickness (CCT) is a biometric entity ${ }^{(14-15)}$, and its biological variability in healthy eyes is believed to result from different amounts of collagen fibrils and interfibrillary substance in the corneal stroma ${ }^{(7,16)}$. It is a measure of tissue mass and perhaps an estimator of corneal rigidity ${ }^{(7)}$. However, CCT varies among ethnic groups and also demonstrates strong heritability in nuclear families ${ }^{(17-18)}$.

The in vivo measurement of corneal resistance to deformation was enabled by the development of the ocular response analyzer (ORA) by Luce ${ }^{(19)}$. The ORA (Reichert Ophthalmic Instruments, New York, USA) determines corneal biomechanical metrics (CH and CRF) using an applied force - displacement relationship.

Our group has studied corneal biomechanical metrics in different scenarios. In a population of healthy subjects ${ }^{(5)}$, we have found that corneal biomechanical metrics and CCT are strongly associated, while showing an inverse relationship with older age, and higher values in females. In a small sample of patients with unilateral / asymmetrical keratoconus(20), CH and CRF values were not statistically different between the studied groups, although a trend for lower values was found for keratoconus and fellow eyes versus the control group. When comparing 77 eyes from 43 patients with keratoconus and 86 eyes from 43 healthy controls (unpublished data), a statistical difference in $\mathrm{CH}$ and $\mathrm{CRF}$ was found between groups, but, when considered individually, the measures demonstrated low sensitivity, specificity, and test accuracy for keratoconus and healthy cornea differentiation. Similar findings were found by our group regarding $\mathrm{CH}$ and $\mathrm{CRF}$ in patients with mild keratoconus(21) and also in cases of keratoconus with CCT $\geq 520 \mu \mathrm{m}^{(8)}$. In the present study, we investigated corneal biomechanical metrics in healthy eyes with CCT $\leq 505 \mu \mathrm{m}$ and compared them with gender-, age-, and CCT-matched keratoconus cases.

\section{METHODS}

We used a prospective, comparative case series design. The research followed the tenets of the Declaration of Helsinki and was approved by the ethics committee of the Federal University of São Paulo, Brazil (protocol 0123/06). Subjects were informed of the purpose of the study, and all gave informed consent before inclusion.

Each subject underwent a comprehensive ophthalmologic examination, including a review of their medical history, best-corrected visual acuity, slit lamp biomicroscopy, fundoscopic examination, Placido disc topography (Humphrey ATLAS, Carl Zeiss Meditec, Dublin, CA, USA) Pentacam tomographic evaluation (Oculus, Wetzlar, Germany) and ORA measurements (Reichert Ophthalmic Instruments, New York, USA).

Diagnosis of keratoconus was made by clinical (corneal stromal thinning, Vogt's striae, Fleischer ring, scissoring of the red reflex or oil droplet sign identified by retinoscopy) and topographic evaluation (increased area of corneal power surrounded by concentric areas of decreasing power, inferior-superior power asymmetry, and skewing of the steepest radial axis above and below the horizontal meridian ${ }^{(22-24)}$.
Healthy eyes with CCT $\leq 505 \mu \mathrm{m}$ were matched with keratoconus cases according to CCT ( $\pm 15 \mu \mathrm{m})$, age ( \pm 6 years) and gender. For analysis, we used CCT instead of the thinnest point (given by the Pentacam) because the air-jet delivered by the ORA is directed at the corneal center. Additionally, a CCT match of $\pm 15 \mu \mathrm{m}$ was chosen based on the work by Khachikian et al. ${ }^{(15)}$, which showed that the average pachymetric difference between fellow healthy eyes was $8.8 \pm 7.2 \mu \mathrm{m}$ at the corneal apex and $8.9 \pm 8.3 \mu \mathrm{m}$ at the pupil center. Our patients were divided in two groups for data comparison: the healthy thin cornea group and the keratoconus group.

Exclusion criteria were age less than 18 years, any previous corneal or ocular surgery, eye disease other than keratoconus (in particular, endothelial dysfunction or dystrophy), chronic or continuous use of topical medications, corneal scars or opacities, and refusal to provide informed consent. Contact lenses had to be removed at least 72 hours before the examination.

Patients underwent testing with the ORA, corneal topography, and Pentacam during the same visit by a trained ophthalmic technician. All measurements were made between 8 am and $6 \mathrm{pm}$. Two consecutive ORA measurements were made (only good-quality readings, as defined by the manufacturer, were recorded), and the results were averaged. CCT was determined using the Pentacam rotating Scheimpflug camera.

Previously, we published a detailed description of the Pentacam system $^{(5)}$, as have other investigators ${ }^{(25-26)}$. Briefly, a rotating camera is set to take 25 - slit images of the anterior eye segment in approximately 2 seconds with 500 true elevation points incorporated in each slit image. CCT is measured in each of the single images of a scan, giving accurate, repeatable, and reproducible measurements.

Details of the ORA have been described extensively ${ }^{(5,8,19,21)}$. Briefly, a precisely metered air pulse is delivered to the eye, causing the cornea to move inwards, past applanation, and into slight concavity. Milliseconds after the initial applanation, the air pump generating the air pulse is shut off and the pressure applied to the eye decreases in an inverse-time, symmetrical fashion. As the pressure decreases, the cornea passes through a second applanated state, while returning from concavity to its normal convex curvature. The energy adsorbed during the rapid corneal deformation delays the occurrence of the inward and outward applanation signal peaks, resulting in a difference between the applanation pressures. The difference between these inward and outward motion applanation pressures is the corneal hysteresis $(\mathrm{CH})$ and is an indication of viscous damping in the cornea, reflecting the capacity of corneal tissue to absorb and dissipate energy. The corneal resistance factor (CRF) is a measure of the cumulative effects of both the viscous and elastic resistance encountered by the air jet while deforming the corneal surface; it is an indicator of the overall resistance of the cornea. The CRF was derived empirically to maximize the correlation with the central corneal thickness (D. Luce. Methodology for Cornea Compensated IOP and Corneal Resistance Factor for the Reichert Ocular

Table 1. Summary data from the study groups

\begin{tabular}{lccc}
\hline & Healthy thin corneas & Keratoconus & p value* \\
\hline Gender & $16 \mathrm{~F} / 14 \mathrm{M}$ & $16 \mathrm{~F} / 14 \mathrm{M}$ & $\mathrm{p}=1$ \\
Age $($ years $)$ & $40.33 \pm 17.38$ & $40.30 \pm 11.73$ & $\mathrm{p}=0.5103$ \\
range & $(20-77)$ & $(22-76)$ & \\
$\mathrm{CCT}(\mu \mathrm{m})$ & $485.96 \pm 17.61$ & $483.64 \pm 16.19$ & $\mathrm{p}=0.5225$ \\
range & $(438-505)$ & $(452-505)$ & \\
$\mathrm{CH}(\mathrm{mmHg})$ & $8.63 \pm 1.23$ & $(4.9-9.85)$ & $\mathrm{p}=0.0312$ \\
range & $(5.95-12.2)$ & $7.22 \pm 1.34$ & $\mathrm{p}<0.0010$ \\
$\mathrm{CRF}(\mathrm{mmHg})$ & $8.43 \pm 1.29$ & $(4.7-9.45)$ & \\
range & $(5.45-11.10)$ & &
\end{tabular}

*Welch modified two-sample $t$-test

$\mathrm{M}=$ male; $\mathrm{F}=$ female; $\mathrm{CCT}=$ central corneal thickness; $\mathrm{CH}=$ corneal hysteresis; $\mathrm{CRF}=$ corneal resistance factor 
Response Analyzer. Invest Ophthalmol Vis Sci. 2006;47:E-Abstract 2266), and it can be considered to be weighted by the elastic resistance because of its stronger correlation with the central corneal thickness than with $\mathrm{CH}$. Although $\mathrm{CH}$ and $\mathrm{CRF}$ are related, they can differ significantly in some instances, and each provides distinct information about the cornea.

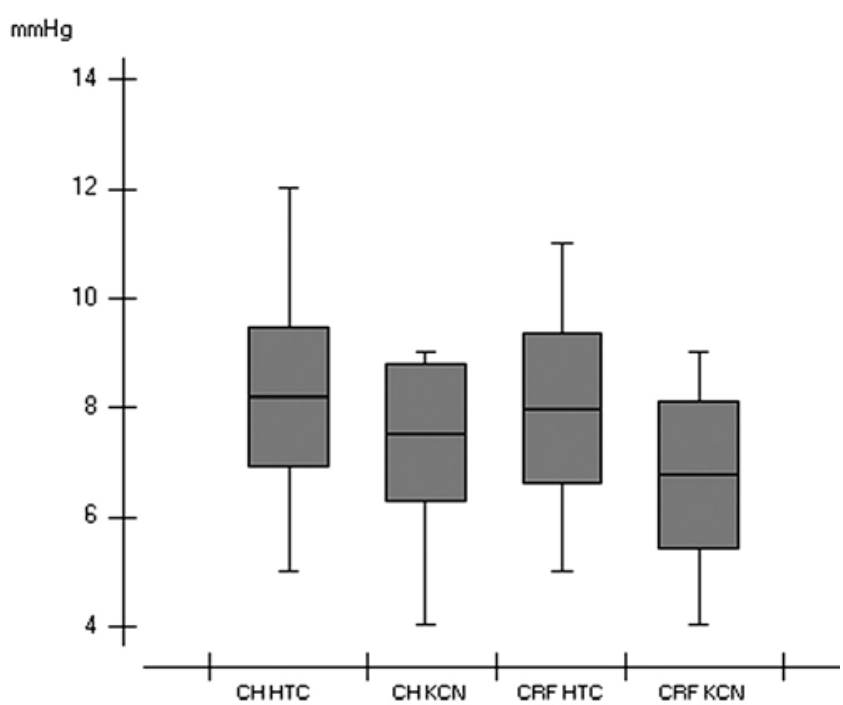

Figure 1. Box-plot distribution of corneal hysteresis $(\mathrm{CH})$ and corneal resistance facto (CRF) in healthy thin corneas (HTC) and keratoconus (KCN).

Table 2. Data from the receiver operating characteristic (ROC) curves (plots of the sensitivity vs. 1 - specificity) for $\mathrm{CH}$ and CRF in the population studied. Due to the substantial overlap between the groups, the ROC curve analyses showed poor overall predictive accuracy of CH and CRF for differentiating healthy thin corneas from keratoconus in the eyes studied

\begin{tabular}{lcccc}
\hline $\begin{array}{c}\text { Cut-off point } \\
\mathbf{m m H g}\end{array}$ & $\begin{array}{c}\text { Sensitivity } \\
\text { (\%) }\end{array}$ & $\begin{array}{c}\text { Specificity } \\
\text { (\%) }\end{array}$ & $\begin{array}{c}\text { Test accuracy } \\
\text { (\%) }\end{array}$ \\
\hline $\mathrm{CH}$ & 8.95 & 63.0 & 23.8 & 44.30 \\
$\mathrm{CRF}$ & 7.40 & 28.3 & 40.5 & 34.12 \\
\hline
\end{tabular}

$\mathrm{CH}=$ corneal hysteresis $; \mathrm{CRF}=$ corneal resistance factor
Statistical analysis were performed using BioEstat 5.0 software (Federal University of Belém, PA, Brazil). The receiver operating characteristic (ROC) curve was used to identify the best $\mathrm{CH}$ and CRF cut-off points to maximize the sensitivity and specificity for discriminating mild keratoconus from normal corneas. The ROC curve was obtained by plotting sensitivity against 1 - specificity, calculated for each value observed. Ideally, an area of $100 \%$ indicates that the test perfectly discriminates between groups. Logistic regression was used to support the cut-off point identified in the ROC curve analysis. Differences between data were evaluated using the Welch modified two-sample $t$-test. Data are expressed as the mean \pm standard deviation.

\section{RESULTS}

In total, 46 eyes from 30 healthy patients with CCT $\leq 505 \mu \mathrm{m}$, and 42 eyes from 30 CCT-, gender- and age-matched keratoconus cases were enrolled.

The central corneal thickness (CCT) was $485.96 \pm 17.61 \mu \mathrm{m}$ (range, 438 - 505) in healthy thin corneas and $483.64 \pm 16.19 \mu \mathrm{m}$ (range, 452 - 505) $\mu \mathrm{m}$ in keratoconus Group; $p=0.5225$.

Corneal hysteresis $(\mathrm{CH})$ was $8.63 \pm 1.23 \mathrm{mmHg}$ (range, $5.95-12.2$ ) in healthy thin corneas and $8.07 \pm 1.17 \mathrm{mmHg}$ (range, $4.9-9.85$ ) in keratoconus group; $p=0.0312$. Corneal resistance factor (CRF) was $8.43 \pm 1.29 \mathrm{mmHg}$ (range, $5.45-11.10$ ) in healthy thin corneas and $7.22 \pm 1.34 \mathrm{mmHg}$ (range, 4.7 - 9.45) in keratoconus group; $p<0.001$.

The results are summarized in table 1. A box-plot of the distribution of $\mathrm{CH}$ and $\mathrm{CRF}$ in healthy thin corneas (HTC) and keratoconus $(\mathrm{KCN})$ is shown in figure 1.

ROC curve analysis showed poor overall predictive accuracy of both corneal hysteresis and corneal resistance factor for discriminating healthy eyes with CCT $\leq 505 \mu \mathrm{m}$ and those with keratoconus. For $\mathrm{CH}$, the optimal cut-off point was $8.95 \mathrm{mmHg}$, with $63 \%$ sensitivity and $23.8 \%$ specificity (test accuracy, $44.30 \%$ ). The best cut-off point for CRF was $7.4 \mathrm{mmHg}$, with $28.3 \%$ sensitivity and $40.5 \%$ specificity (test accuracy, 34.12\%). Data from the ROC curves are presented in table 2.

\section{DISCUSSION}

Corneal biomechanical metrics are known to have a strong correlation with central corneal thickness and to be affected by aging ${ }^{(5,27)}$. Additionally, our first study in healthy patients found statistically significantly higher values in females(5). Thus, we consider it important that these variables be matched when comparing $\mathrm{CH}$ and $\mathrm{CRF}$

Table 3. Values of "normality" from some published studies (data expressed as mean \pm standard deviation)

\begin{tabular}{|c|c|c|c|c|}
\hline Paper & yes studied & CCT $(\mu \mathrm{m})$ & $\mathrm{CH}(\mathrm{mmHg})$ & CRF (mmHg) \\
\hline Fontes et $\mathrm{al}^{(13)}$ & 260 & $\begin{array}{l}545.05 \pm 35.41 \\
\text { Range } 454-640\end{array}$ & $\begin{array}{c}10.17 \pm 1.82 \\
\text { Range } 3.23-14.58\end{array}$ & $\begin{array}{c}10.14 \pm 1.80 \\
\text { Range } 5.45-15.10\end{array}$ \\
\hline Che et $a l^{(79)}$ & 43 & $\begin{array}{l}549.87 \pm 29.53 \\
\text { Range } 493-617\end{array}$ & $\begin{array}{c}11.52 \pm 1.28 \\
\text { Range } 9.25-14.30\end{array}$ & $\begin{array}{c}11.68 \pm 1.40 \\
\text { Range } 8.55-14.70\end{array}$ \\
\hline Medeiros et $a^{\mid(80)}$ & 153 & $\begin{array}{c}538 \pm 35 \\
\text { Range } 414-627\end{array}$ & Not provided & $\begin{array}{c}9.47 \pm 1.75 \\
\text { Range } 4.68-14.15\end{array}$ \\
\hline Kamiya et al(56) & 86 & $\begin{array}{c}540 \pm 31 \\
\text { Range } 476-598\end{array}$ & $\begin{array}{c}10.20 \pm 1.3 \\
\text { Range } 6.7-13.3\end{array}$ & Not provided \\
\hline Shah et $a^{(81)}$ & 110 & $\begin{array}{c}546.5 \pm 33 \\
\text { Range } 467-640\end{array}$ & $\begin{array}{c}11.4 \pm 1.9 \\
\text { Range } 6.4-16.7\end{array}$ & $\begin{array}{c}10.0 \pm 1.6 \\
\text { Range } 6.6-14.9\end{array}$ \\
\hline Franco et al $\left.\right|^{(64)}$ & 63 & $\begin{array}{c}534 \pm 33.1 \\
\text { Range } 448.3-610.7\end{array}$ & $\begin{array}{c}10.8 \pm 1.53 \\
\text { Range } 8.3-15.5\end{array}$ & $\begin{array}{c}10.6 \pm 1.71 \\
\text { Range } 6.9-14.9\end{array}$ \\
\hline $\begin{array}{l}\text { Luce D, Taylor D } \\
\text { (ORA brochure, 2005) }\end{array}$ & 5) 339 & Not provided & $\begin{array}{c}12.36 \pm 1.90 \\
\text { Range } 7.73-18.01\end{array}$ & $\begin{array}{c}12.34 \pm 2.08 \\
\text { Range } 6.49-18.09\end{array}$ \\
\hline
\end{tabular}

$\mathrm{CCT}=$ central corneal thickness; $\mathrm{CH}=$ corneal hysteresis; $\mathrm{CRF}=$ corneal resistance factor 
in different groups. When publishing about ORA corneal biomechanical metrics, authors should separate patients into groups in terms of factors known to influence them. A number of "normal" values for $\mathrm{CH}$ and $\mathrm{CRF}$ in healthy corneas found in previously published studies are shown in table 3.

Keratoconic eyes have a low tensile strength, thinning, and protrusion ${ }^{(12,21-22,24)}$. Our findings show that the lower resistance to deformation in keratoconus group is not due only to thinning, because the groups were matched by thickness. Additionally, higher corneal resistance after collagen cross-linking is often accompanied by thinning ${ }^{(28-29)}$. Therefore, corneal rigidity and resistance to deformation are likely affected by unknown factors in addition to corneal thickness ${ }^{(12)}$. Thus, reduced central corneal thickness is only part of the answer. The corneal stromal collagen fibrils of keratoconus patients are probably more fragile, more readily deformable by the air-jet, and perhaps thinner than those of normal subjects.

We found substantial overlap in the values of $\mathrm{CH}$ and CRF between the groups (Figure 1). Data recently published by Qazi et al. ${ }^{(30)}$ indicate that waveform parameters provided by the ORA signal may contain additional important information that, could be more sensitive than $\mathrm{CH}$ or CRF in discriminating abnormal corneas. Additional studies are needed to determine whether signal analysis is useful in biomechanical studies of the cornea.

In conclusion, $\mathrm{CH}$ and CRF were statistically lower in keratoconus eyes than in matched thin healthy corneas. However, because of the large overlap between the groups, $\mathrm{CH}$ and CRF both had low sensitivity and specificity for discriminating between the two groups. Further research on new technologies for corneal stiffness measurement and biomechanical variability is warranted.

\section{REFERENCES}

1. De Benito-Llopis L, Alió JL, Ortiz D, Teus MA, Artola A. Ten-year follow-up of excimer laser surface ablation for myopia in thin corneas. Am J Ophthalmol. 2009;147(5):768-73, 773.e1-2.

2. Kymionis GD, Bouzoukis D, Diakonis V, Tsiklis N, Gkenos E, Pallikaris Al, et al. Long-term results of thin corneas after refractive laser surgery. Am J Ophthalmol. 2007;144(2):181-5. Comment in: Am J Ophthalmol. 2007;144(2):284-5.

3. Tabbara KF, Kotb AA. Risk factors for corneal ectasia after LASIK. Ophthalmology. 2006; 113(9):1618-22

4. Condon PI. 2005 ESCRS Ridley Medal Lecture: will keratectasia be a major complication for LASIK in the long term? J Cataract Refract Surg. 2006;32(12):2124-32.

5. Fontes BM, Ambrosio R Jr, Alonso RS, Jardim D, Velarde GC, Nosé W. Corneal biomechanical metrics in eyes with refraction of -19.00 to $+9.00 \mathrm{D}$ in healthy Brazilian patients. J Refract Surg. 2008;24(9):941-5.

6. Uçakhan OO, Ozkan M, Kanpolat A. Corneal thickness measurements in normal and keratoconic eyes: Pentacam comprehensive eye scanner versus noncontact specular microscopy and ultrasound pachymetry. J Cataract Refract Surg. 2006:32(6):970-7.

7. Ehlers N, Hjortdal J. Corneal thickness: measurement and implications. Exp Eye Res. 2004; 78(3):543-8. Review.

8. Fontes BM, Ambrosio R Jr, Velarde GC, Nose W. Ocular response analyzer measurements in keratoconus with normal central corneal thickness compared with matched normal control eyes. J Refract Surg. 2010 May 19:1-7. [Epub ahead of print].
9. Konstantopoulos A, Hossain P, Anderson DF. Recent advances in ophthalmic anterior segment imaging: a new era for ophthalmic diagnosis? Br J Ophthalmol. 2007;91 (4):551-7.

10. Ambrosio R Jr, Alonso RS, Luz A, Coca Velarde LG. Corneal-thickness spatial profile and corneal-volume distribution: tomographic indices to detect keratoconus. J Cataract Refract Surg. 2006;32(11):1851-9.

11. Roberts C. Biomechanical customization: the next generation of laser refractive surgery. J Cataract Refract Surg. 2005;31(1):2-5.

12. Roberts C. The cornea is not a piece of plastic. J Refract Surg. 2000:16(4):407-13. Comment in: J Refract Surg. 2001;17(1):76-7; author reply 77-8. J Refract Surg. 2001;17(1):76; author reply 77-8.

13. Krueger RR. Biomechanical manipulation: the next frontier in corneal refractive surgery. J Refract Surg. 2009;25(10):837-40. Comment on: J Refract Surg. 2009;25(10):855-61. J Refract Surg. 2009;25(10):847-54.

14. Doughty MJ, Zaman ML. Human corneal thickness and its impact on intraocular pressure measures: a review and meta-analysis approach. Surv Ophthalmol. 2000;44(5):367-408.

15. Khachikian SS, Belin MW, Ciolino JB. Intrasubject corneal thickness asymmetry. J Refract Surg. 2008;24(6):606-9.

16. Boote C, Hayes S, Abahussin M, Meek KM. Mapping collagen organization in the human cornea: left and right eyes are structurally distinct. Invest Ophthalmol Vis Sci. 2006;47(3): 901-8.

17. Torres RJ, Jones E, Edmunds B, Becker T, Cioffi GA, Mansberger SL. Central corneal thickness in Northwestern American Indians/Alaskan Natives and comparison with White and African-American persons. Am J Ophthalmol. 2008;146(5):747-51.

18. Aghaian E, Choe JE, Lin S, Stamper RL. Central corneal thickness of Caucasians, Chinese, Hispanics, Filipinos, African Americans, and Japanese in a glaucoma clinic. Ophthalmology. 2004;111(12):2211-9.

19. Luce DA. Determining in vivo biomechanical properties of the cornea with an ocular response analyzer. J Cataract Refract Surg. 2005;31(1):156-62.

20. Fontes BM, Ambrosio R Jr, Salomão M, Velarde GC, Nosé W. Biomechanical and tomographic analysis of unilateral keratoconus. J Refract Surg. 2010;26(9):677-81.

21. Fontes BM, Ambrosio R Jr, Jardim D, Velarde GC, Nosé W. Corneal biomechanical metrics and anterior segment parameters in mild keratoconus. Ophthalmology. 2010;117(4):673-9.

22. McMahon TT, Szczotka-Flynn L, Barr JT, Anderson RJ, Slaughter ME, Lass JH, lyengar SK; CLEK Study Group. A new method for grading the severity of keratoconus: the Keratoconus Severity Score (KSS). Cornea. 2006;25(7):794-800

23. Rabinowitz YS. Keratoconus. Surv Ophthalmol. 1998;42(4):297-319.

24. Reeves SW, Ellwein LB, Kim T, Constantine R, Lee PP. Keratoconus in the Medicare population. Cornea. 2009;28(1):40-2.

25. Piñero DP, Alió JL, Alesón A, Escaf M, Miranda M. Pentacam posterior and anterior corneal aberrations in normal and keratoconic eyes. Clin Exp Optom. 2009;92(3):297-303.

26. Kawamorita T, Uozato H, Kamiya K, Bax L, Tsutsui K, Aizawa D, Shimizu K. Repeatability, reproducibility, and agreement characteristics of rotating Scheimpflug photography and scanning-slit corneal topography for corneal power measurement. J Cataract Refract Surg. 2009;35(1):127-33.

27. Kamiya K, Hagishima M, Fujimura F, Shimizu K. Factors affecting corneal hysteresis in normal eyes. Graefes Arch Clin Exp Ophthalmol. 2008;246(10):1491-4.

28. Vinciguerra $P$, Albè E, Trazza $S$, Rosetta $P$, Vinciguerra R, Seiler T, Epstein D. Refractive, topographic, tomographic, and aberrometric analysis of keratoconic eyes undergoing corneal cross-linking. Ophthalmology. 2009;1 16(3):369-78. Comment in: Ophthalmology. 2009;116(10):2036-7; author reply 2037-8.

29. Grewal DS, Brar GS, Jain R, Sood V, Singla M, Grewal SP. Corneal collagen crosslinking using riboflavin and ultraviolet-A light for keratoconus: one-year analysis using Scheimpflug imaging. J Cataract Refract Surg. 2009;35(3):425-32.

30. Qazi MA, Sanderson JP, Mahmoud AM, Yoon EY, Roberts CJ, Pepose JS. Postoperative changes in intraocular pressure and corneal biomechanical metrics Laser in situ keratomileusis versus laser-assisted subepithelial keratectomy. J Cataract Refract Surg. 2009; 35(10):1774-88 